\title{
PALAEOKARST DEPOSITS IN CAVES: EXAMPLES FROM EASTERN AUSTRALIA AND CENTRAL EUROPE
}

\author{
PALEOKRAŠKI SEDIMENTI V JAMAH: PRIMERI IZ VZHODNE \\ AVSTRALIJE IN SREDNJE EVROPE
}

\author{
R. Armstrong L. OSBORNE ${ }^{1}$
}

\begin{abstract}
UDC 551.44:551.3.051(94+4) R. Armstrong L. Osborne: Palaeokarst deposits in caves: Examples from Eastern Australia and Central Europe

Palaeokarst deposits are most commonly found in excavations, drill holes and naturally exposed at the Earth's surface. Some caves however intersect palaeokarst deposits. This occurs in large hypogene caves in the USA, thermal caves in Hungary and in many caves in eastern Australia. Palaeokarst deposits in caves respond to cave forming processes in the same way as hostrock: the palaeokarst deposits form cave walls. A range of palaeokarst deposits is exposed in caves including; filled tubes, walls composed of flowstone, large-scale bodies, breccia pipes, dykes, volcaniclastic palaeokarst and crystalline palaeokarst. As well as being exposed in cave walls, palaeokarst deposits can wholly or partly form speleogens (speleogens made from palaeokarst). Records of geological events not preserved elsewhere can occur in palaeokarst deposits in caves. These can be difficult to correlate with conventional geological histories. It is important to be able to distinguish between palaeokarst deposits, relict sediments and phantom rock (in-situ weathered rock, also called ghost rock; Vergari \& Quinif 1997). Relict sediments can be distinguished from palaeokarst deposits because the cave walls bound relict sediments while palaeokarst deposits form the cave walls. Palaeokarst can be distinguished from phantom rock, as palaeokarst is unconformable with the hostrock, with structures in the hostrock not continuing across the boundary into the palaeokarst. Hostrock structures and textures do continue across the boundary between unaltered hostrock and phantom rock. Similarly, cave sediments are unconformable or disconformable with the hostrock while phantom rock is conformable with hostrock containing hostrock structures and textures. It has been difficult to explain why palaeokarst occurs in some caves and not others. One explanation worth considering is that palaeokarst deposits are not intersected by caves or sections of caves that contain large perennial streams and/or have undergone large-scale vadose fluvial development capable of escaping from the bounds of structural guidance, such as the caves in the Classical Karst.

Key words: palaeokarst, caves, Australia, relict sediments, phantom rock.
\end{abstract}

Izvleček UDK 551.44:551.3.051(94+4)

R. Armstrong L. Osborne: Paleokraški sedimenti v jamah: primeri iz vzhodne Avstralije in Srednje Evrope

Paleokraške sedimente največkrat najdemo v izkopih, vrtinah in izdankih na zemeljskem površju. Tudi kraške jame lahko sekajo peleokraške sedimente. Najbolj znane po tem so velike hipogene jame v ZDA, na Madžarskem in številne jame vzhodne Avstralije. Paleokraški sedimenti tako kot prikamnina tvorijo jamske stene. $\mathrm{V}$ jamah najdemo različne oblike paleokraških sedimentov: zapolnjene cevi, stene iz paleokraške sige, velika sedimentna telesa, cevi breče, dajke, vulkanoklastični paleokras in kristalinski paleokras. Poleg tega tudi jamske skalne oblike delno ali povsem nastajajo na paleokraških sedimentih. Ti v jamah nosijo tudi zapise preteklih dogajanj, ki se drugje niso ohranili, a je te zapise velikokrat težko povezati z ostalimi. Pomembno je razlikovati med paleokraškimi sedimenti, reliktnimi jamskimi sedimenti in fantomsko kamnino (in situ preperelo kamnino, $\mathrm{v}$ angleščini imenovano tudi ghost rock; Vergari \& Quinif 1997). Reliktne jamske sedimente lahko ločimo od paleokraških, ker jamske stene predstavljajo meje prvih, medtem ko paleokraški sedimenti sestavljajo jamsko steno. Paleokraški sedimenti so praviloma $\mathrm{v}$ nezveznosti $\mathrm{s}$ prikamnino, kar velja tudi za jamske sedimente. Po drugi strani pa struktura in tekstura nespremenjene prikamnine prehajata $\mathrm{v}$ fantomsko kamnino. Zakaj je paleokras prisoten le v določenih jamah, je težko odgovoriti. Morda je pomenljivo, da paleokrasa praviloma ne najdemo $\mathrm{v}$ jamah $\mathrm{z}$ aktivnimi vodotoki oziroma $\mathrm{v}$ jamah, ki so v razvoju prešle obdobje vadoznega rečnega vrezovanja, kot je to značilno za jame Klasičnega krasa.

Ključne besede: paleokras, jame, Avstralija, reliktni sedimenti, fantomska kamnina.

${ }^{1}$ Sydney School of Education \& Social Work, A35, The University of Sydney, NSW, 2006, Australia, e-mail: armstrong.osborne@sydney.edu.au

Received/Prejeto: 01.08.2016 


\section{INTRODUCTION}

Since 1982 I have been studying palaeokarst deposits in the caves of eastern Australia. Of the more than 300 cavernous karsts in eastern Australia 19 have caves that intersect palaeokarst deposits. These include four of the best-known and most cavernous karsts in New South Wales: Jenolan, Wombeyan, Bungonia and Yarrangobilly. In Tasmania, caves are known to intersect palaeokarst deposits at three localities: Mole Creek, Junee-Florentine and Ida Bay. Caves in eastern Australia do not just intersect a single palaeokarst deposit; some intersect palaeokarst deposits of several different types and ages.

During the 1980s and 1990s there were few reports of palaeokarst in caves. There was also little mention of palaeokarst in caves even in compilations dedicated to palaeokarst, such as Bosák, Ford, Głazek and Horáček (1989), and James and Choquette (1988).

In 1995 Derek Ford, citing US examples, Jewel and Wind Caves in South Dakota and Lechuguilla Cave and Carlsbad Caverns, in New Mexico, suggested that intersection of palaeokarst might be more likely in caves formed by per-ascensum processes than in caves formed by per-descensum processes. This would explain the abundance of palaeokarst deposits intersected by the Hungarian thermal caves. No one in the mid 1990s, however, would have suggested that hypogene caves occurred in eastern Australia and few outside Hungary and Poland would have suggested their presence in Continental Europe. So there was a problem. Why were palaeokarst exposures in caves apparently rare and restricted to "unusual" caves in Europe and North America but abundant in what were considered "normal" caves in eastern Australia? Had palaeokarst deposits in caves been unrecognised elsewhere or were eastern Australian caves somehow "unusual"?

A visit to the Classical Karst of Slovenia in 1997 revealed palaeokarst in road cuttings, in the seashore and in quarries, even palaeokarst with dinosaur bones, but no palaeokarst deposits were seen exposed in the walls of caves. So it did seem that the intersection of palaeokarst by caves was rare in Continental Europe. Noticeably, in the recent review of palaeokarst by Plotnick, Kenig and Scott (2015) all of the illustrations are of palaeokarst exposures in quarries, so palaeokarst exposures in caves continue to be left in the dark.

\section{WHERE DO CAVES WITH PALAEOKARST OCCUR?}

There is good documentation of caves intersecting palaeokarst deposits in Australia, the Czech Republic, Hunga- ry, Slovakia, USA, and UK, and there are reports of caves intersecting palaeokarst deposits in Brazil, Estonia, Israel and South Africa. Some well-documented localities are given in Tab. 1, below.

\section{THE SPECIAL CASE OF EASTERN AUSTRALIA}

With palaeokarst deposits recognized in caves in most of the karst areas in eastern Australia where significant scientific investigation has taken place, it is worth noting the geological and geomorphic characteristics of eastern Australia.

The Palaeozoic rocks of eastern Australia form the Tasman Orogen, which has been progressively accreted to the craton. In the south and the west, the Proterozoic Adelaide Orogen lies between the Tasman Orogen and the craton, forming the western half of Tasmania, where significant caves are developed in primary dolomite and magnesite.

The telogenic caves of eastern Australia (Tasmanic Caves) are developed in Palaeozoic limestones of the Tasman Orogen. Most of the caves are developed in small, impounded karsts. These caves are relatively small and shallow, with most less than $3 \mathrm{~km}$ long and $50 \mathrm{~m}$ deep. Most of these caves lack permanent streams.

The Tasman Orogen is divided into two major zones, the western Lachlan-Thompson Orogen and the eastern New England Orogen now separated by the Permo-Triassic Sydney-Bowen Basin (Fig. 1). In the Lachlan-Thompson Orogen the last folding was in the Early Carboniferous while in the New England Orogen the last folding was in Permo-Triassic times. Cavernous limestones in the Lachlan-Thompson Orogen are Ordovician to Mid-Devonian tropical island arc shelf deposits, while cavernous limestones in the New England Orogen are Devonian olistoliths and Permian cold-water shelf deposits.

The landscape of eastern Australia consists from east to west of a narrow coastal plain, the Great Escarpment (Ollier 1982), the Eastern Highlands Plateaux and the Western Slopes and Plains. The last significant glaciation in mainland Australia occurred in Permo-Carboniferous times. The Eastern Highlands Plateau was uplifted in the Late Cretaceous with localized uplifts in the Tertiary. While there has been neotectonic activity in Tasmania and Victoria, there is little evidence of neotectonic activity further north.

With the last major uplift in the Cretaceous, coupled with limited and slow geomorphic development and little meteoric cave development in the Cenozoic it is not surprising that ancient caves and ancient cave deposits could survive in eastern Australia. 
Tab. 1: Some caves and karsts with palaeokarst deposits.

\begin{tabular}{|c|c|}
\hline LOCATION & SOURCE \\
\hline Nullarbor Plain, Australia & $\begin{array}{l}\text { H. Shannon, pers. } \\
\text { communication }\end{array}$ \\
\hline Borenore, NSW, Australia & Osborne 1984 \\
\hline Bungonia, NSW, Australia & Osborne 1984, 1993a \\
\hline Jenolan, NSW, Australia & $\begin{array}{l}\text { Osborne 1984, 1991, } \\
\text { 1993b }\end{array}$ \\
\hline Timor, NSW, Australia & Osborne 1986 \\
\hline Wombeyan, NSW, Australia & Osborne $1984,1993 c$ \\
\hline $\begin{array}{l}\text { Cathedral Cave, Wellington, } \\
\text { NSW, Australia }\end{array}$ & Osborne $2007 c$ \\
\hline Ida Bay, Tasmania, Australia & Osborne \& Cooper 2001 \\
\hline My Cave, Mole Creek, Tasmania & Osborne 2007d \\
\hline Jewel and Wind Caves, SD, USA & Bakalowicz et al. 1987 \\
\hline Grand Canyon, USA & Wenrich \& Sutphin 1994 \\
\hline $\begin{array}{l}\text { Lechuguilla Cave and Carlsbad } \\
\text { Caverns, NM, USA }\end{array}$ & D. C. Ford 1995 \\
\hline Cayman Islands & Jones \& Smith 1988 \\
\hline Peak District, UK & T. D. Ford 1989 \\
\hline $\begin{array}{l}\text { Wet Sink Cave, Forest } \\
\text { of Dean, UK }\end{array}$ & $\begin{array}{l}\text { D. Lowe, observed by } \\
\text { author } 1979\end{array}$ \\
\hline Bihor Mountains, Romania & Ghergari et al. 1997 \\
\hline Moravia, Czech Republic & $\begin{array}{l}\text { J. Otava, observed by } \\
\text { author } 2013\end{array}$ \\
\hline $\begin{array}{l}\text { Okno Cave, Demänovská } \\
\text { Valley, Slovakia }\end{array}$ & Osborne 2007b \\
\hline Budapest, Hungary & Korpás 1998 \\
\hline $\begin{array}{l}\text { Siebenhengste Region, } \\
\text { Switzerland }\end{array}$ & Häuselmann 2002 \\
\hline Israel & $\begin{array}{l}\text { A. Frumkin, pers. } \\
\text { communication. }\end{array}$ \\
\hline Estonia & $\begin{array}{l}\text { Tõnu Pani, pers. } \\
\text { communication. }\end{array}$ \\
\hline
\end{tabular}

\section{DEFINITION OF PALAEOKARST}

There have been many attempts to define palaeokarst.

One of the best-known definitions is that of James and Choquette $(1988$, p. 2). They defined paleokarst as: "Ancient karst, which is commonly buried by younger sediments or sedimentary rocks and thus includes both relict paleokarst (present landscapes formed in the past) and buried paleokarst (karst landscapes buried by sediments)."

Osborne (2000) noted that this definition did not assist in distinguishing between relict features and what he considered to be "truly palaeokarst features formed during an ancient period of karstification and remaining as inherited or relict features in the landscape or rock mass" (Osborne 2000, p.114).

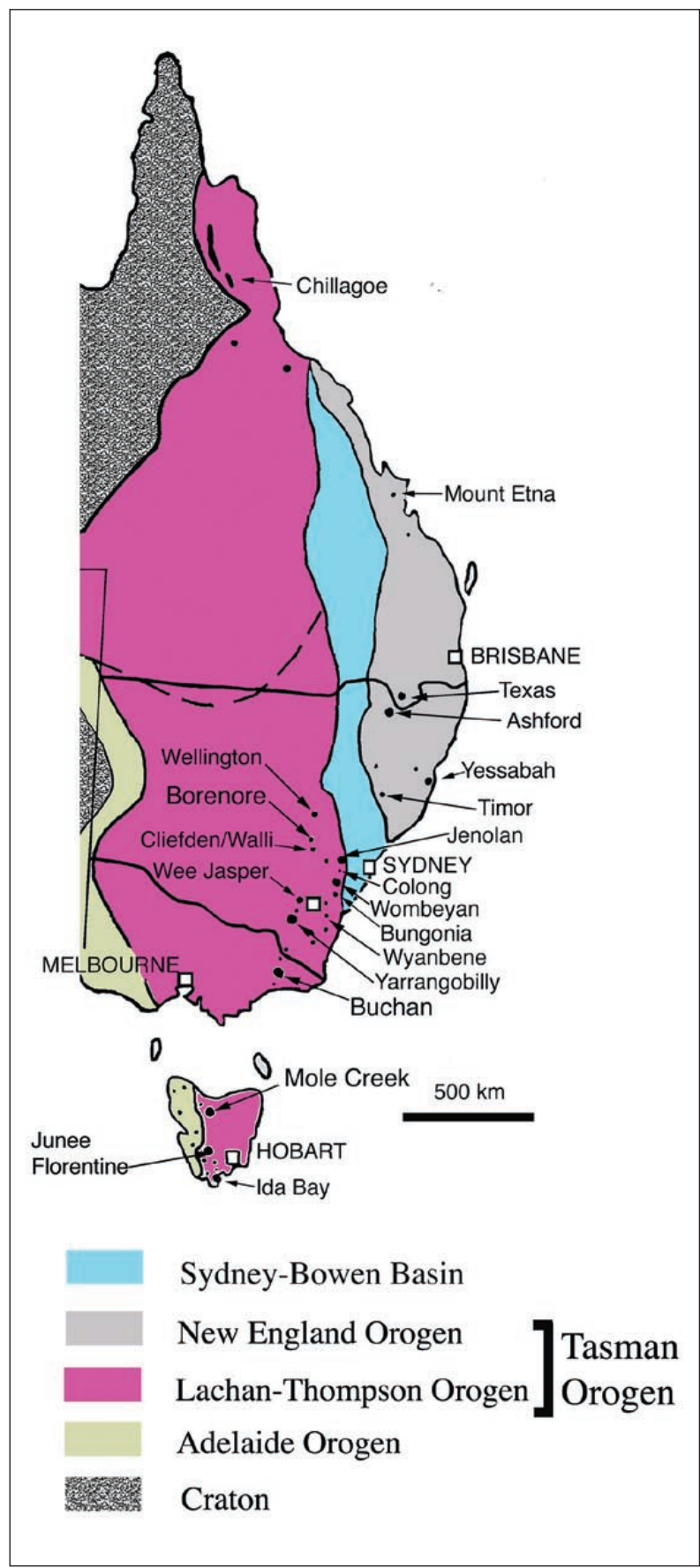

Fig. 1: Eastern Australia showing principal tectonic zones and 20 major cavernous karsts. (Modified after Fig. 1 in Osborne (2010)).

James and Choquette's definition raises another important issue. Their definition is about landscapes, but most of the features described in this paper are sedimentary rocks. So are the cavities these deposits fill palaeokarst, but not the deposits themselves? 
Jennings (1982) considered that the term "palaeokarst" was "problematic". He proposed that paleokarst should only refer to karst features that are older than the last regional orogeny. If this criterion were applied in Eastern Australia, palaeokarst could only refer to features or sediments that were older than Permian, early Carboniferous or Mid Devonian, depending in their location. Most of the palaeokarst deposits that have been identified in Eastern Australia and described in this paper were deposited directly after last regional orogeny and are unconformable with the host rock and their bedding is generally aligned to the present horizontal. These would not be palaeokarst sensu Jennings (1982).

Bosák, Ford, Głazek and Horáček (1989) gave the definition that "Paleokarst refers to karst developed largely or entirely during past geological periods". This definition relies on the ability to date karst features, both landforms and deposits, but as Osborne (2005) showed, dating karst landforms and deposits is difficult, unreliable and may produce uncertain and controversial results.

Ford and Williams (1989, p. 507) distinguished between "relict karsts", "paleokarsts or buried karsts" and "exhumed karsts". This distinction was based on the degree of coupling between the features and the present hydrogeological system with paleokarsts and buried karsts "completely decoupled from the present hydrogeological system". A similar definition is found on p. 3 of Ford \& Williams (2007).

Wright and Smart (1994) defined paleokarst with the statement that: "Paleokarst refers to karstic (dissolution-related features) formed in the past, related to an earlier hydrological system or landsurface." By this defi- nition many of the features described here are not palaeokarst as they are depositional (sediments, speleothems crystal masses etc.) not dissolutional features.

James \& Choquette (1988) were clear that palaeokarst is composed of old karst landscapes, while with Wright and Smart the focus is on dissolutional features. Bosák, Ford, Głazek and Horáček (1989) just mention karst, but if we look at the chapter by Bosák, Horáček and Panoš (1989) on Paleokarst of Czechoslovakia in Bosák, Ford, Głazek and Horáček (1989) we see that their view of paleokarst is very broad and geological, involving large-scale geological history, paleogeography, sediments, fossils, ore minerals, caves and a time-scale extending over 500 million years.

Recognising that paleokarst was difficult to define and that the term was used to describe a great range of features, Osborne (2004) provided the following inclusive Encyclopaedia definition: "Paleokarst is evidence for karst processes acting in the past." Noting that: "This definition intentionally includes both karst landforms formed in the past and deposits that fill them" (Osborne 2004, p. 559).

A working definition for palaeokarst deposits in caves is that in caves palaeokarst deposits react to cave forming processes in the same way as the hostrock does. Thus cave walls are continuous across palaeokarst exposures. Speleogens (hostrock solutional features in caves) can be wholly or partially composed of palaeokarst. Sediments in some Australian caves are hundreds of millions of years old but are not considered palaeokarst because they are not lithified, do not behave like hostrock and are enclosed by a cave wall rather than being part of a cave wall.

\section{PALAEOKARST DEPOSITS IN CAVES}

\section{FILLED TUBES AND PHREATIC CAVES IN SPELEOTHEM}

The most convincing examples of palaeokarst deposits exposed in caves are sections through tubes in cave walls filled with lithified sediments. The exposure in Okno Cave, Slovakia (Fig. 2A) is an outstanding example of this type of exposure. The intersected cavity is $2.7 \mathrm{~m}$ high and $1.5 \mathrm{~m}$ at it's widest and is filled by graded-bedded mudstone, siltstone and sandstone (Osborne 2007b). Differential weathering of the fill has resulted in the partial exhumation of the tube in the upper part of the exposure, with the lower part of the fill protruding into the younger intersecting passage.

Phreatic caves formed in speleothem are also convincing examples of palaeokarst deposits exposed in caves.
Fig. 2B shows part of the cave wall in Main Cave at Timor, NSW, Australia. To the left we see a complex smooth wall in massive limestone hostrock, while from the middle to the right we see the cave wall is composed of palaeoflowstone overlying sediment filling the palaeokarstic cavity. At the point of the red arrow we can see that the wall surface continues unchanged across the boundary between the hostrock and the palaeokarst flowstone. Timor Main Cave is located high in the landscape and has phreatic speleogens, some developed in the palaeoflowstone. Osborne (1986) concluded that the phreatic re-excavation of a cave largely filled with palaeoflowstone was a result of the watertable rising after the adjacent valley filled with Eocene basalt. 


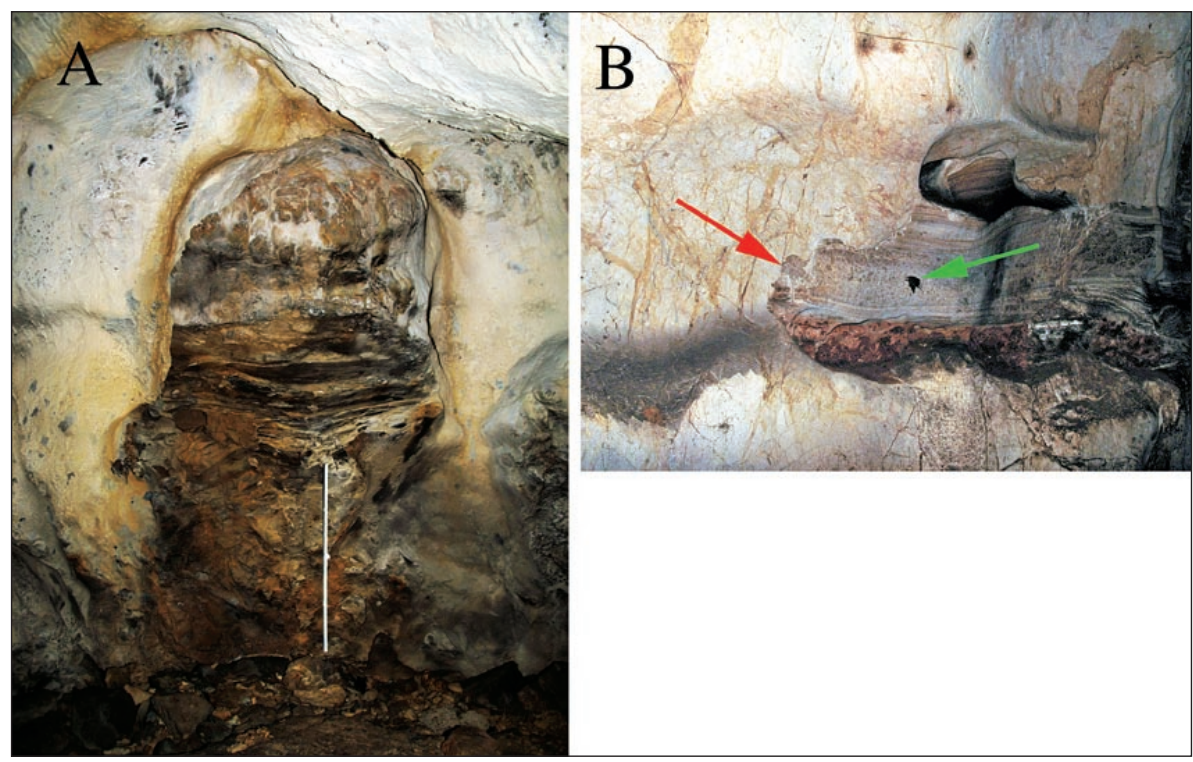

Fig. 2: A= Lithified palaeokarst deposit in Okno Cave, Slovakia; white rule for scale is $1 \mathrm{~m}$. Note how the brown palaeokarst deposit fills a hollow in the massive limestone cave wall, after Osborne 2007b. B= Wall of Main Cave, Timor NSW, Australia. Red arrow points to boundary between the hostrock (left) and the flowstone palaeokarst (right). Green arrow points to microbat for scale.

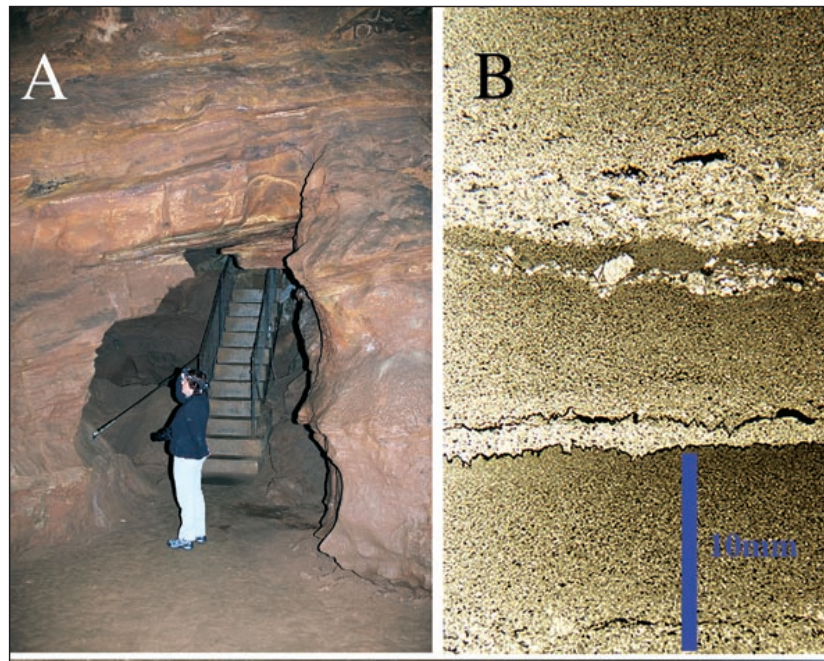

\section{LARGE-SCALE BODIES}

Large-scale bodies of palaeokarst fill can have significant solutional caves developed within them, without exposing the hostrock. Osborne (1991) described a mass of caymanite palaeokarst exposed continuously for more than 70 metres along strike in the lower southern section of Jenolan Caves, NSW, Australia. Fragmentary exposures of the deposit suggest that it is approximately 400 metres long and 10 metres wide. Fig. $3 \mathrm{~A}$ shows part of the type section through the deposit where a continuous cross-section, 5.5 metres thick is exposed. This section also exposes the upper contact with the enclosing steeply dipping massive limestone hostrock. The rock in this deposit is a graded-bedded carbonate with crinoid ossicles in some of the coarser layers (Fig. 3B) making it a caymanite (palaeokarst cavity filled by predominantly marine sediments in coastal settings; Jones 1992). Some parts of the contemporary cave are formed entirely within the mass of palaeokarst (Fig. 3C).

\section{BRECCIA PIPES}

The formation of palaeokarst breccia pipes has often been related to solution collapse processes involving the removal of gypsum, e.g. Friedman (1997). Breccia pipes can also be seen forming today in situations not involving sulfate removal. An active non-sulfate breccia pipe occurs in Mladeceske Cave in the Czech Republic (Fig. 4A). The Palaeozoic limestones in eastern Australia are not interbedded with gypsum, but breccia pipes are developed in them. An ancient breccia pipe, probably of Late Devonian age has been intersected by Cathedral Cave at Wellington Caves, NSW, Australia (Fig. 4B). The large clasts in the pipe are 


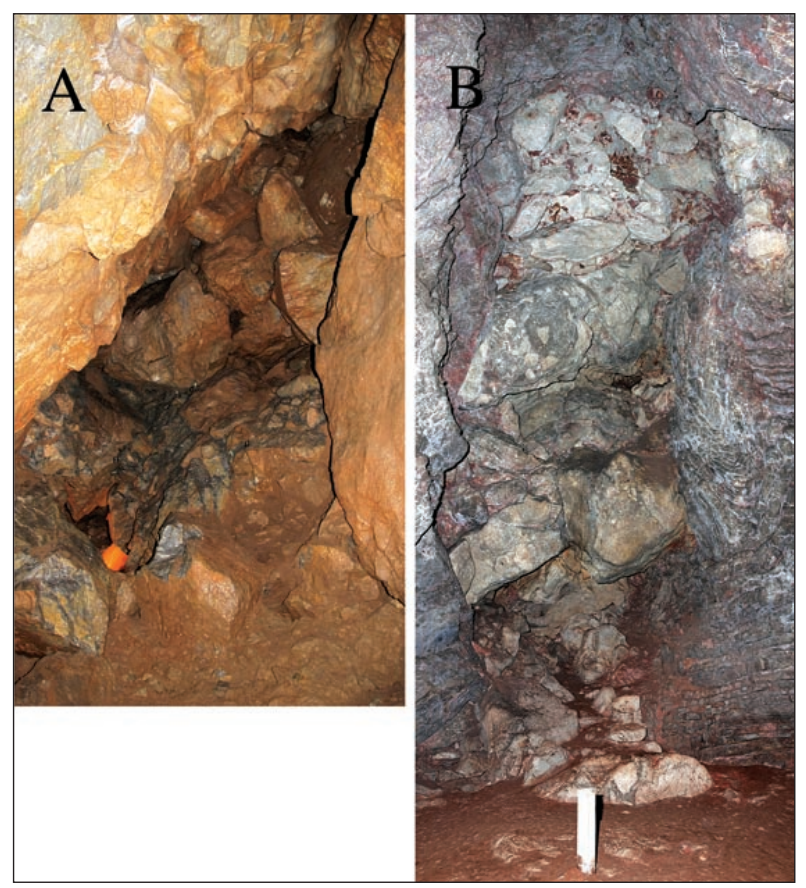

Fig. 4: A= Contemporary non-sulfate breccia pipe in Mladeceske Cave, Czech Republic. Base of breccia pipe is approx. $2 \mathrm{~m}$ wide. $B=$ Palaeokarst breccia pipe, Wellington Caves, NSW, Australia; white post is $0.9 \mathrm{~m}$ high.

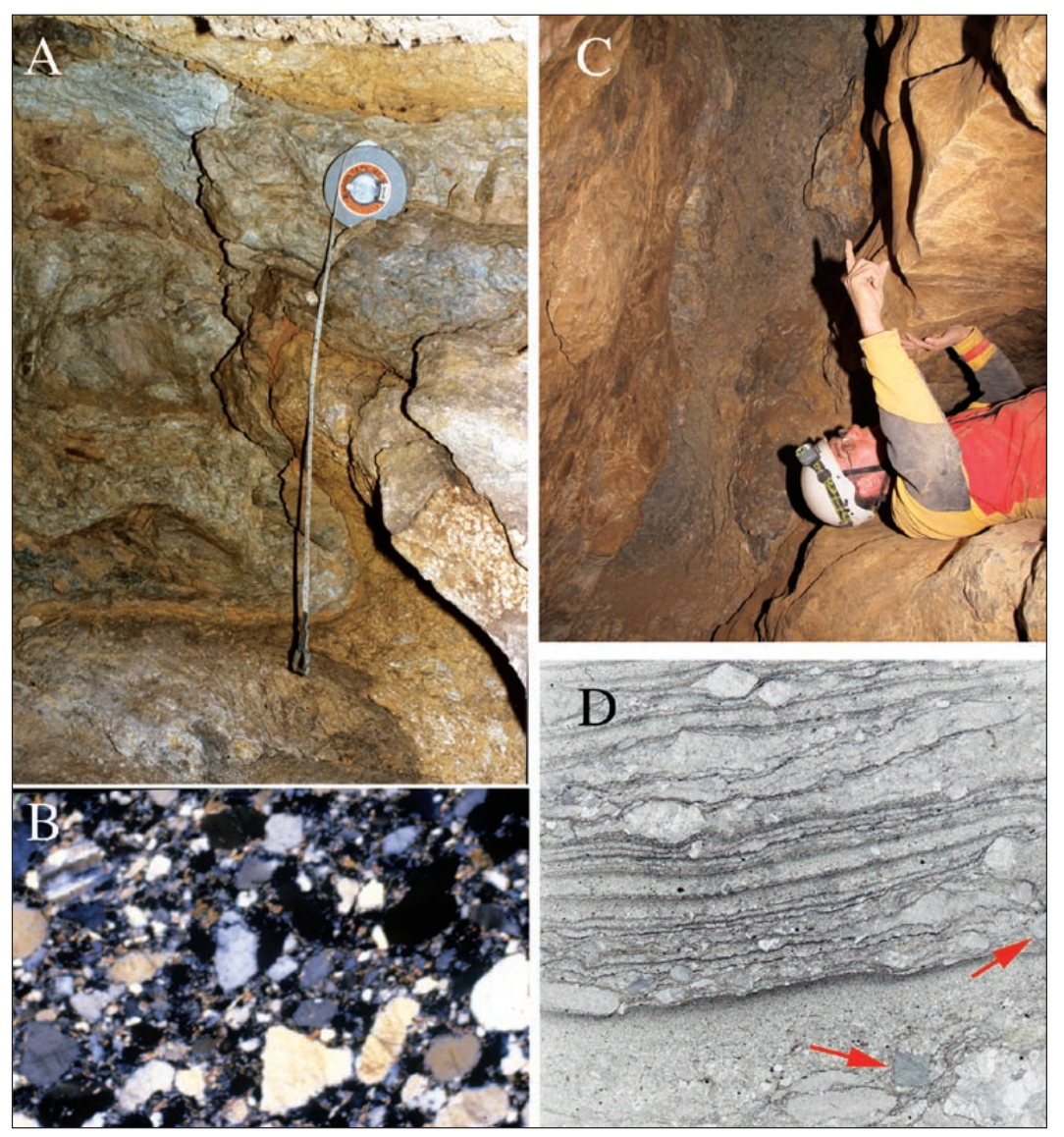

mostly massive limestone while the walls of the pipe are composed of intensely folded thinly bedded limestone. The red matrix between the large clasts is composed of calcite, kaolinite and quartz.

\section{DYKE-LIKE FEATURES}

It is not uncommon for caves in eastern Australia to intersect igneous dykes, but reports of dykes in caves elsewhere are uncommon. Dyke-like features in caves include conventional igneous dykes, altered igneous dykes, clastic dykes, caymanite dykes, pyroclastic dykes and Neptunian dykes. Figs. 5A and B show a clastic dyke intersected by Grill Cave at Bungonia, NSW, while Figs. $5 \mathrm{C}$ and $\mathrm{D}$ show a caymanite dyke intersected by Hogan Cave at Bungonia, NSW. Most dyke-like features exposed in caves are highly weathered so it is very difficult in the field to distinguish between a weathered dolerite dyke and a clastic dyke with ferruginous cement. Cavers frequently miss-identify dykes often confusing them with shale beds and vice-versa. In some situations, dolerite dykes can be completely altered to calcite (see Osborne 2003) and in the field could be miss-interpreted as a carbonate palaeokarst deposit.

Intrusive, clastic and caymanite dykes found in caves are not always vertical but can be dipping, following dipping conjugate joints (Fig. 5A). As well as filling with clastics; grikes and cave passages guided by joints can fill with lava, fossilizing them (making them palaeokarst features). As Osborne (2005) discussed, it is very difficult to distinguish between lava filled joint-guided cavities (palaeokarst) and intrusive dykes (not palaeokarst) in caves.

Fig. 5: A= Dipping clastic dyke in Grill Cave, Bungonia Caves, NSW, Australia. B= Thin section of clastic dyke in "A," note matrix and lack of carbonate cement. Sand grains are approx. $0.5 \mathrm{~mm}$ in diameter. $C=D y k e$ like joint-filling of carbonate palaeokarst (dark material adjacent to author's helmet), Hogan Cave, Bungonia Caves, NSW, Australia (Photo: J. Sydney). $D=$ Thin section of joint filling of carbonate palaeokarst in " $C$ ", red arrows point to crinoid fragments approx. $1 \mathrm{~mm}$ in size. 

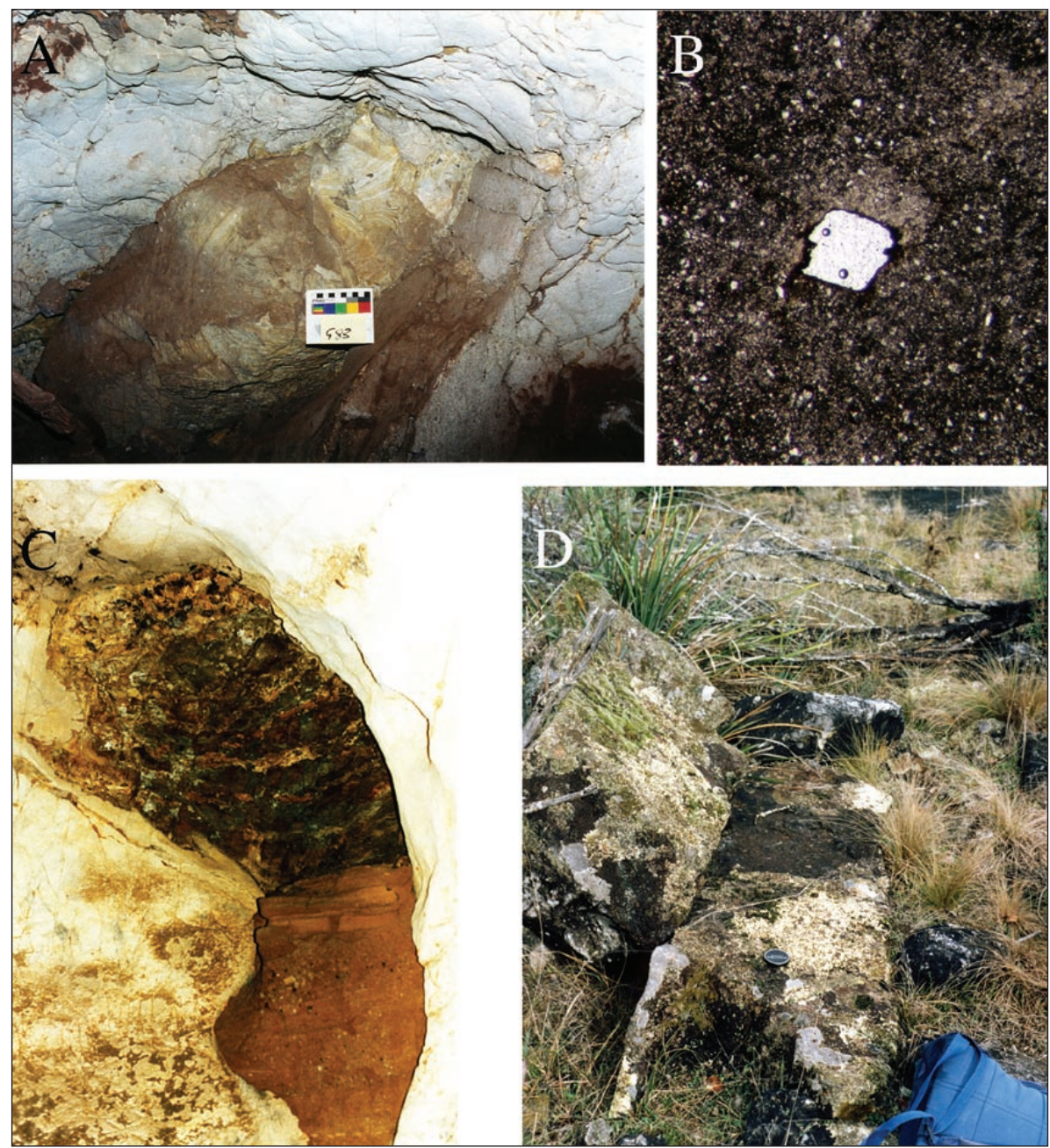

Fig. 6: A= Volcaniclastic palaeokarst deposit with liesegang banding filling a tube in the wall of Cathedral Cave, Wellington Caves, NSW, Australia. B= Thin section of palaeokarst in "A" showing calcite pseudomorph after augite in glassy groundmass. Pseudomorph is $1 \mathrm{~mm}$ across. $C=$ Filled tube in upper wall of Bullio Cave, Wombeyan Caves, NSW, Australia. Upper dark layered deposit is laminated volcaniclastics. Lower brown, layered deposit is younger sediment unconformably abutting the palaeokarst. Tube is approx. $1 \mathrm{~m}$ wide at top of brown deposit. $D=$ Surface exposure of pyroclastic dyke with lens cap $(55 \mathrm{~mm})$ standing out above dissolving marble bedrock.

\section{VOLCANICLASTIC PALAEOKARST}

Volcaniclastic palaeokarst is produced when tephra either from ash falls or mudflows enters caves or karst depressions, becomes lithified and is later intersected by the development of a new system of cavities. In eastern Australia volcaniclastic palaeokarst deposits in caves have been identified at two localities, Wellington Caves and Wombeyan Caves. In Cathedral Cave at Wellington Caves (Osborne 2007c) pyroclastics with liesegang banding are found filling tubes in massive limestone (Fig. 6A). In thin section pesudomorphs of calcite after augite stand out against a dark grey glassy groundmass (Fig. 6B).

At Wombeyan Caves, marmorized Silurian limestone is unconformably overlain by volcaniclastics of the Bindook Porphyry Complex, a Devonian mega-Plinian assemblage (Osborne 1993c). Palaeokarst deposits found at Wombeyan include intersected volcaniclastic-filled tubes (Fig. 6C) and pyroclastic dykes exposed both in the caves and at the surface (Fig. 6D).

Osborne (2007a) suggested that pyroclastic palaeokarst deposits should be much more widespread than currently reported given the abundance of stratovolcanoes in both modern and ancient island arcs where much of the world's limestone was and is being deposited.

\section{CRYSTALLINE PALAEOKARST}

There are two main types of crystalline palaeokarst, crystalline breccias and crystal vughs.

\section{Crystalline Breccias}

Crystalline breccias are composed of angular fragments, of mostly hostrock, separated by a crystalline matrix. Based largely on drill hole data, Loucks (2007), interpreted cave breccias, which he considered to be "paleocave facies" as the product of caves collapsing due to burial and he developed a scheme for classifying them. While Loucks envisaged these breccias as being formed at the end of a cave's history, it is not rare to find "paleocave" breccias as the hostrock of quite intact caves. Loucks' first category, crackle breccias, have minor displacement between clasts that appear to fit together. Fig. 7A shows a body of crackle breccia exposed in the cave wall of Creek 

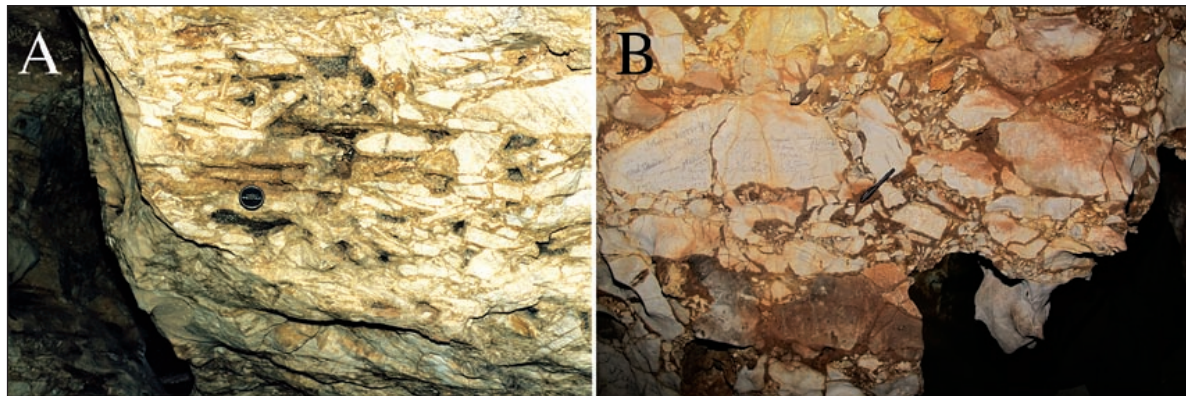

Fig. 7: A= Crackle breccia with party aligned clasts, Creek Cave, Wombeyan Caves, NSW, lens cap is $55 \mathrm{~mm}$. B=Crystal breccia, Basin Cave, Wombeyan Caves, NSW, black pen in centre field is $150 \mathrm{~mm}$ long. $C=$ Matrixsupported chaotic crystal breccia with rotated blocks in the ceiling of Chifley Cave, Jenolan Caves, NSW. Blocks in the breccia are
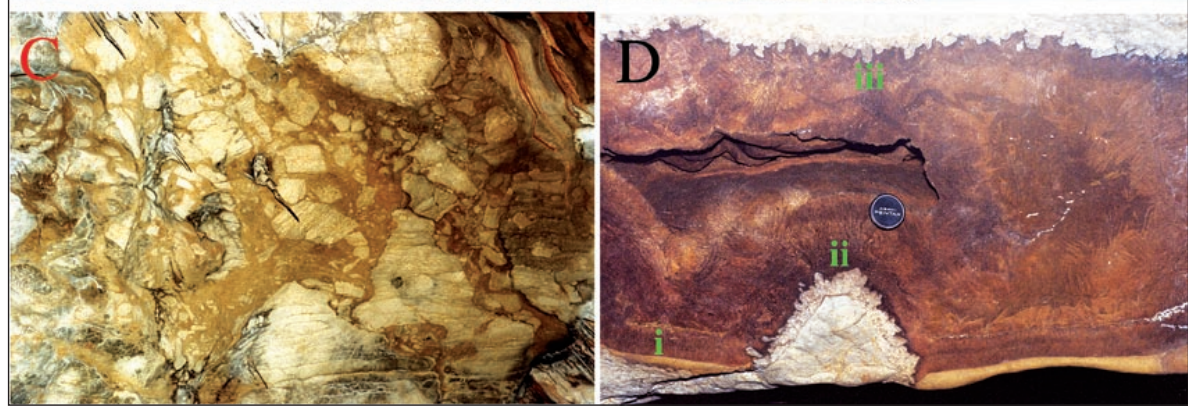

$1 \mathrm{~m}+$ across. $\mathrm{D}=$ Crystalline palaeokarst vugh with geopetal sediment, Imperial Cave, Jenolan Caves, NSW, lens cap is $55 \mathrm{~mm}$.

Cave an ephemeral stream cave at Wombeyan Caves, NSW. The clasts are composed of marble while the matrix is crystalline calcite. A smaller scale crystal breccia with more angular clasts is shown in Fig. 7B. In this case although they are widely separated by matrix, some clasts do fit together making it a "mosaic" breccia. Fig. 7C, an image looking up into the ceiling of Katie's Bower, a solution chamber in Chifley Cave at Jenolan Caves, NSW, shows large hostrock blocks, $1 \mathrm{~m}+$ floating in a crystalline matrix. Traces of bedding in the blocks suggest that some have rotated. Some of the blocks are sub-rounded indicating solution during emplacement of the matrix. This is an example of a "matrix-supported chaotic breccia" of Loucks (2007). An alternative and older interpretation of crystal breccias in karst was given by Sass-Gustkiewicz (1974) who considered them to have a solutional origin.

Unless there is clear evidence that the breccia fills a karst void, it is very difficult to be sure that these breccias are palaeokarst features rather than the products of nonkarst tectonic and hydrothermal processes.

\section{Palaeokarst Crystal Vughs}

Cave passages can intersect crystal-lined vughs that are not related to the processes that formed the contemporary caves. Vughs can range in size from decimetres to tens of metres. Care must be taken not to confuse intersected palaeokarst crystal vughs with the remnants of more recent crystal linings that are filling indentations in the contemporary cave wall. Young sediments can be deposited in the open spaces of ancient vughs, so care must also be taken not to confuse unconsolidated ancient and modern fillings in vughs. The vugh in Fig. 7D is one of many vughs exposed over a distance of at least 50 metres in the walls and ceiling of the Imperial Cave at Jenolan Caves, NSW (Osborne 1984). Fig. 7D shows a number of important features of the crystal vughs. At the base (i) we see geopetal sediment aligned to the present horizontal, indicating that there has been no tectonism since deposition. In the centre (ii) there is a bedrock relic coated with large white crystals, which are also visible at the top of the vugh (iii).

\section{SPELEOGENS IN PALAEOKARST}

Since palaeokarst deposits in caves behave like hostrock, it should not be surprising to find speleogens developed wholly or partly in palaeokarst. These are formed as a result of later periods of speleogenesis and include pendants (Fig. 8A), juts (projections from cave walls), cers (projections from cave floors), and bridges (Fig. 8B).

\section{DEMARCATION OF PALAEOKARST}

Distinguishing palaeokarst from other features in caves is not simple and can be controversial. Large prominent objects can prove to be the most difficult to interpret. An excellent example is the large caymanite deposit shown in Fig. 3. Before this deposit was recognised, small deposits of laminated sediment had been noted elsewhere in Jenolan Caves and dismissed as shale beds in the Silurian limestone sequence. In 1984 it became clear that these deposits were unconformable with the Silurian hostrock. The large mass of gently dipping laminated limestone in Fig. 3A was first recognised as a palaeokarst deposit in July 1986. Its notable feature is the unconformable boundary with the hostrock, best seen in Fig. 9A. It was difficult to imagine that such a large mass of limestone could be a palaeokarst deposit so alternative explanations 


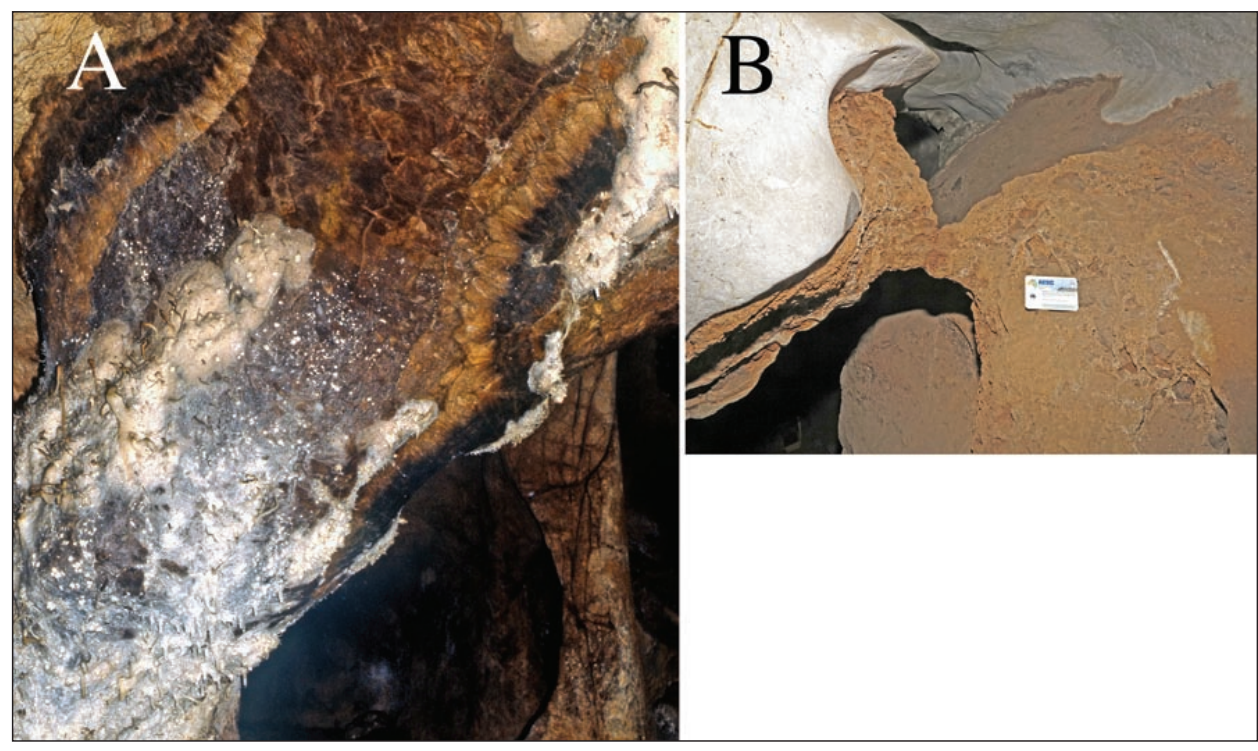

Fig. 8: A= Pendant composed of crystalline palaeokarst, Imperial Cave, Jenolan Caves, NSW, Australia. $B=$ Bridge composed of poorly lithified clay, Gable Cave, Cliefden Caves, NSW, Australia.

that it was a fault block or a tight fold in the bedrock were explored and rejected principally because it has a sutured unconformable boundary with the hostrock and showed no evidence of either folding or faulting. As the deposit was strongly lithified and behaved like hostrock it had to be palaeokarst. In the late 1980s it was thought that old sediments in caves should be high in the landscape and younger sediments should be lower in the landscape as the cave worked its way down through the limestone. This deposit was clearly very old, but it was in the lowest part of the cave system, close to the watertable. Time constraints on this deposit place it between the last folding of the limestone (Early Carboniferous) and the limestone's burial under the Sydney Basin (Late Carboniferous to Early Permian). If this deposit had been composed of bedded terrigenous mud with marine fossils it would have not been controversial, as there are Permian marine mudstones and glacial marine sediments $17 \mathrm{~km}$ east of Jenolan and the caves were probably once buried under these strata. The nearest Carboniferous limestones are located $212 \mathrm{~km}$ northeast of Jenolan, so the occurrence of marine carbonate palaeokarst at Jenolan is controversial and an enigma.

\section{FEATURES ON THE BOUNDARY OF PALAEOKARST}

The bridge in Gable Cave, Cliefden Caves, NSW shown in Fig. 8B is composed of very poorly lithified clay and does not behave like cave wall material. However during the most recent phase of flooding and sediment removal it has proved sufficiently lithified to form a respectable phreatic speleogen. Fig. 9B shows poorly lithified red sediment in Swansong Cave at Cliefden Caves, NSW, the cave directly above where the bridge in palaeokarst in Fig. $8 \mathrm{~B}$ is located. In Fig. 9B, directly above the caver's head, we see a mass of red sediment behaving as hostrock forming the cave wall and the cave ceiling inside the older limestone hostrock ceiling. In both cases the materials involved are poorly lithified and probably relatively young, but as they respond to speleogenetic processes in the same way as hostrock, both deposits are considered to be palaeokarst.

\section{PALAEOKARST DEPOSITS VS RELICT SEDIMENT}

Some Australian caves contain sediments that are hundreds of millions of years old (Osborne et al. 2006). These sediments are not considered palaeokarst because they are not behaving like hostrock, but partly fill a cave enclosed by hostrock walls (Fig. 9C). Despite their great age these sediments are not lithified which illustrates an issue raised by Osborne (2005), the "lithification trap". Geologists often assume that lithified sediments must be older than unlithified ones, but in caves where the main process of lithification is cementation, permeable sediments like sands and gravels can become lithified much more rapidly than impermeable materials such as muds.

\section{PALAEOKARST VS PHANTOM ROCK}

Distinguishing palaeokarst deposits from phantom rock is a confusing issue as phantom rock can itself be palaeokarst (Quinif et al. 2006). The distinction between palaeokarst deposits, partly lithified cave sediments and phantom rock is becoming an important issue as more cases of phantom rock are reported (Dubois et al. 2014) and cave formation by the removal of weathered dolomite, dedolomite and magnesite are being investigated.

Palaeokarst deposits and cave sediments should be unconformable with the hostrock and should have a different texture and composition to the surrounding 

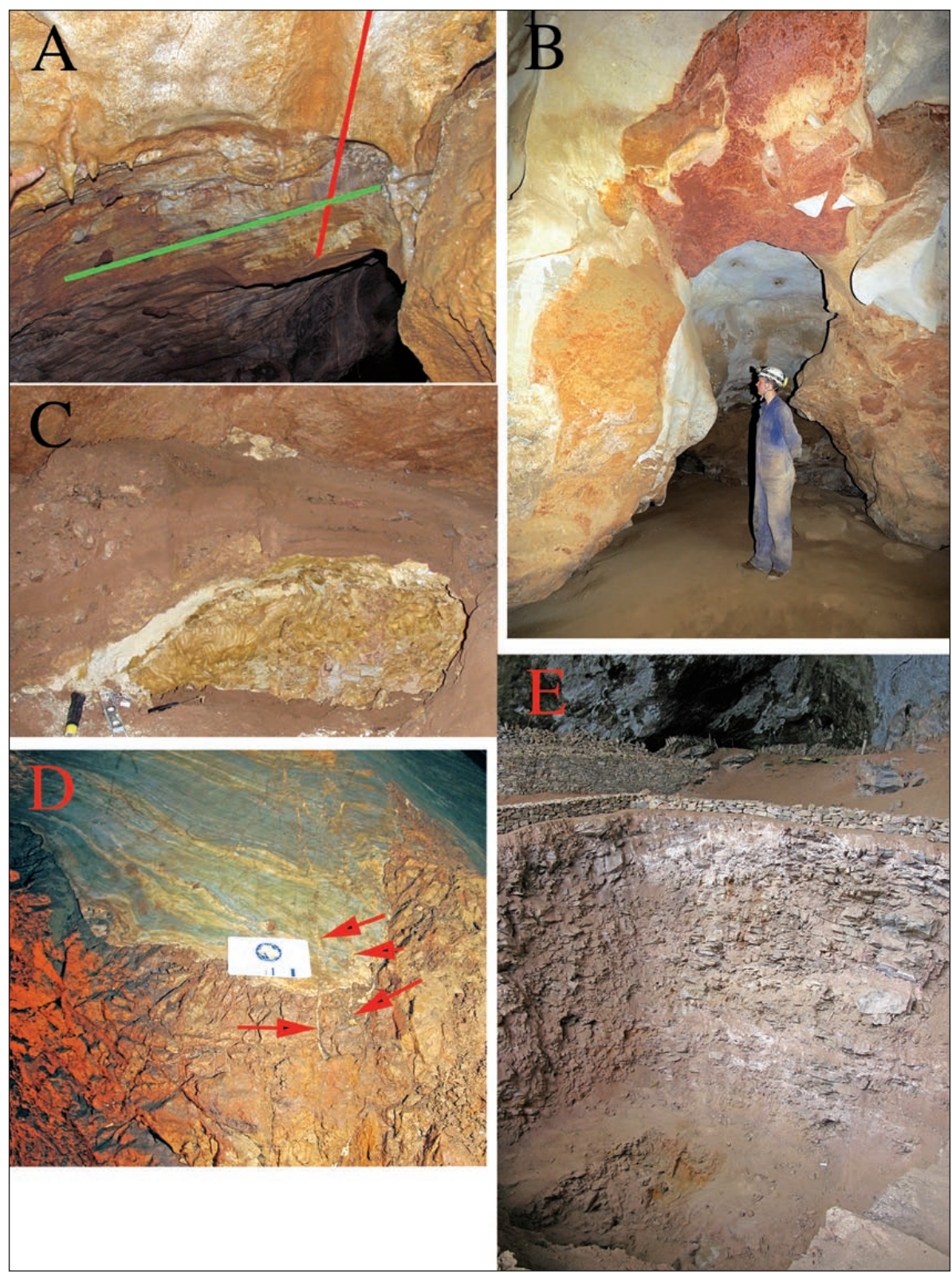

Fig 9: $A=$ Upper unconformable boundary of palaeokarst deposit shown in Fig. 3A (Photo: A. Tyc). Red line indicates trace of bedding in enclosing massive Silurian limestone, green line indicates bedding in palaeokarst deposit. Curved unconformable boundary is the ceiling of the filled ancient cave. $B=$ Poorly lithified sediment, red behaving as cave wall and ceiling so considered to be palaeokarst, Swansong Cave, Cliefden Caves, NSW. C= Deposit of unlithified clay (yellow) dated as Carboniferous by Osborne et al. (2006), Temple of Baal, Jenolan Caves, NSW. Note overlying pink strata and clearly defined cave wall behind. Black sleeve on yellow handle at lower left of image is $100 \mathrm{~mm}$ long. $\mathrm{D}=$ Boundary between whitish hostrock and orange muddy phantom rock. Note sparry veins, indicated by red arrows extending from the hostrock into the phantom rock. $E=6.3 \mathrm{~m}$ deep $\times 10 \mathrm{~m}$ wide archaeological pit inside Fa-Hein Cave, Sri Lanka, in phantomized gneiss mistaken for cave sediment. hostrock. Traces of structures in the hostrock such as veins, bedding, fractures and alignment of clasts and fossils should not continue across the hostrock -palaeokarst unconformity.

In contrast, phantom rock and related altered/ weathered hostrock should have the same large-scale texture and contain the same fossils as the hostrock. In phantom rock the alignment of traces of structures in the hostrock such as veins, bedding, fractures and the alignment of clasts and fossils should continue across the hostrock-phantom rock boundary. This can be seen in Fig. 9D, where sparry veins in the marble hostrock extend into the adjacent muddy orange phantom rock, locally described as ochre.

\section{PHANTOM ROCK VS SEDIMENTS}

Just as phantom rock can be confused with palaeokarst it can also be confused with unconsolidated sediment. Osborne et al. (2013) reported that archaeologists in Sri Lanka had excavated a pit, 6.3 metres deep in phantomized gneiss thinking it was cave sediment, apparently confusing traces of weathered foliation with bedding (Fig. 9E).

\section{WHY DO CAVES IN SOME PLACES INTERSECT PALAEOKARST DEPOSITS?}

T.D. Ford (1976), when discussing the Permian and Carboniferous limestones of the United Kingdom noted that: "any limestone of appreciable age may have gone through 
more than one cycle of karstification", introducing the possibility that in "older" rocks multiple karstification and the intersection of palaeokarst deposits is more likely to occur.

Osborne (1984) found and described palaeokarst deposits in caves at five localities in eastern mainland Australia. These localities were originally selected for investigation because of their close proximity to major unconformities.

In 1995, D.C. Ford suggested that per-ascensum caves are more likely to intersect palaeokarst than perdescensum caves.

Osborne (2000, 2002, $2005 \& 2013)$ suggested caves that are:

1. Located close to major unconformities;

2. Developed in Palaeozoic or older rocks;

3. In small, impounded, karsts with limited potential pathways for cave development, where new caves are more likely to intersect older filled caves;

4. Have strong structural guidance, such as per-ascensum caves;

5. Occur in regions with low erosion rates and where the last tectonism occurred in the distant past;

... are more likely to intersect palaeokarst.
Exceptions to these criteria show which are the key determinants. Henry Shannon (pers. comm.) has identified palaeokarst intersected by caves in the Nullarbor Plain of southern central Australia. The Nullarbor Plain is underlain by Miocene limestone and as the World's largest karst area with an oceanic coastline, cannot be considered to be old, small or impounded. So criteria 2 and 3 are not essential, while Okno Cave in Slovakia is developed in Triassic Limestone, is in a large karst area and is in an area of high erosion with recent tectonism. So criteria 2, 3, and 5 are not essential

This leaves criterion 4, structural guidance and per-ascensum development as key criteria, so D.C. Ford (1995) was right after all.

The exceptions to the rules such as Nullarbor and Okno suggest that the wrong question is being asked. So perhaps it is more useful to ask: - "Which caves do not intersect palaeokarst?"

One possible answer worth further investigation is that: - Palaeokarst deposits and speleogens made from palaeokarst do not occur in caves or sections of caves that contain large perennial streams and/or have undergone large-scale vadose fluvial development capable of escaping from the bounds of structural guidance.

\section{CONCLUSIONS}

Intersection of palaeokarst deposits by caves is common in eastern Australia and occurs in Estonia, Hungary, Israel, Romania, Switzerland, the UK, and in hypogene caves in the USA. These areas do not have a lot in common in terms of hostrock geology, geomorphology, hydrology or climate.

Palaeokarst deposits in caves can be difficult to identify and distinguish from sediments, structural features and phantom rock. Palaeokarst deposits in caves can record events that are not represented elsewhere in the geologic record. These events can be difficult to reconcile with traditional views about regional geological history. This may result in controversy. Speleogens formed from palaeokarst are uncontroversial because if palaeokarst deposits can behave like hostrock and form cave walls, they can also form pendants and juts etc. Why some caves intersect palaeokarst deposits and others do not remains a problem. One possible answer is that exposures of palaeokarst deposits occur in caves that have never had a perennial stream in them or in caves in which there has been minimal fluvial modification.

\section{ACKNOWLEDGEMENTS}

The author would like to thank the many people from different countries who have assisted in the search for and documentation of palaeokarst deposits in caves over the past thirty-four years: In Australia, Tony Allan, David
Branagan, David Colchester, Ian Cooper, Ross Pogson, Henry Shannon, Joe Sydney, John Wylie, Horst Zwingmann, many cave managers, guides and national park staff. In Austria, the late Robert Seemann, In the Czech 
Republic, Pavel Bosák, Vaclav Cilek, Jaroslav Kadlec, Jiri Otava and Karel Zak. In Estonia, Tõnu Pani, In France, Philippe Audra, In Great Britain, Trevor Ford, John Gunn and David Lowe. In Hungary, Katalin BolnerTakács, the late László Korpás, Szabolcs Leél-Õssy and János Móga. In Israel, Amos Frumkin, In Poland, the late Jerzy Głazek, Michał Gradziński, Andrzej Tyc and Jan Urban, In Romania, Tudor Tamas. In Slovakia, Pavel Bella,
Ludovít Gaál, Peter Gažík, Jozef Hlaváč, Josef Psotka and Pavel Staník. In Slovenia, Andrej Kranjc, Andrej Mihevc, Bojan Otoničar, Tadej Slabe, France Šušteršic and Nadja Zupan-Hajna, and in Switzerland, Philipp Häuselmann. Penney Osborne is thanked once again for her attention to detail in reading the proofs. The paper has been improved by suggestions from two anonymous referees.

\section{REFERENCES}

Bakalowicz, M. J., Ford, D. C., Miller, T. E., Palmer, A. N. \& M.V. Palmer, 1987: Thermal genesis of dissolution caves in the Black Hills, South Dakota.- Geological Society of America Bulletin, 99, 729-738. DOI: https://doi.org/10.1130/0016-7606(1987)99<729:tgodci>2.0.co;2

Bosák, P., Ford, D.C., Głazek, J., \& Horácek, I., Eds. 1989: Paleokarst. A Systematic and Regional Review. Elsevier and Academia, pp. 726, Amsterdam and Praha.

Bosák P., Horáček, I. \& V. Panoš.,1989 Paleokarst of Czechoslovakia.- In Bosák, P. et al. (eds.) Paleokarst. A Systematic and Regional Review. Elsevier and Academia, pp. 107-135, Amsterdam and Praha.

Dubois, C., Quinif, Y., Baele, J-M., Barriquand, L., Bini, A., Bruxelles, L., Dandurand, G., Havron, C., Kaufmann, O., Lans, B., Maire, R., J. Martin, J., Rodet, J., Rowberry, M.D. Tognini, P. \& A.Vergari, 2014: The process of ghost-rock karstification and its role in the formation of cave systems.- Earth-Science Reviews, 131,116-148. DOI: https://doi.org/10.1016/j. earscirev.2014.01.006

Ford, D.C., 1995: Paleokarst as a target for modern karstification.- Carbonates and Evaporites, 10, 2, 138-147. DOI: https://doi.org/10.1007/bf03175399

Ford, D.C. \& P.W. Williams, 1989. Karst Geomorphology and Hydrology.- Unwin Hyman, pp. 601, London.

Ford, D.C. \& P.W. Williams, 2007: Karst Hydrogeology and Geomorphology. John Wiley \& Sons, 578 pp, Chichester. DOI: https://doi. org/10.1002/9781118684986.ch5

Ford, T.D., 1976: The geology of caves.- In Ford, T.D. \& C.H.D. Cullingford (eds.) The Science of Speleology. Academic Press, pp. 11-60, London.

Ford, T.D., 1989: Paleokarsts of Britain.- In Bosák, P. et al. (eds.) Paleokarst. A Systematic and Regional Review. Elsevier and Academia, pp. 51-70, Amsterdam and Praha.
Friedman, G.M., 1997: Dissolution-collapse breccias and paleokarst resulting from dissolution of evaporite rocks, especially sulfates.- Carbonates and Evaporites, 12, 53-63. DOI: https://doi.org/10.1007/ bf03175802

Ghergari, L., Tamas, T., Damm, P. \& F. Forray, 1997: Hydrothermal paleokarst in Pestera din Valea Rea (Bihor Mountains, Romania).- Theoretical and Applied Karstology, 10,115-125.

Häuselmann, P., 2002: Cave genesis and its relationship to surface processes: Investigations in the Siebenhengste region (BE, Switzerland).- $\mathrm{PhD}$ thesis. University of Fribourg, pp. 168.

James, N.P \& P.W. Choquette (eds.), 1988: Paleokarst.Springer-Verlag, pp. 416, New York. DOI: https:// doi.org/10.1126/science.240.4855.1071

Jennings, J.N., 1982. Principles and problems in reconstructing karst history.- Helictite, 20, 2, 37-52.

Jones, B., 1992: Caymanite, a cavity-filling deposit in the Oligocene-Miocene Bluff Formation of the Cayman Islands.- Canadian Journal of Earth Science, 29, 720-735. DOI: https://doi.org/10.1139/e92-062

Jones, B. \& D.S. Smith, 1988: Open and filled features on the Cayman Islands: implications for the recognition of paleokarst.- Canadian Journal of Earth Sciences, 25, 1277-1291. DOI: https://doi.org/10.1139/ e88-123

Korpás, L. 1998: Paleokarst studies in Hungary.- Occasional Papers of the Geological Institute of Hungary, 195, 1-139.

Loucks, R.G., 2007: A review of coalesced, collapsedpaleocave systems and associated suprastratal deformation.- Acta Carsologica, 36, 121-132. DOI: https://doi.org/10.3986/ac.v36i1.214

Ollier, C.D., 1982: The Great Escarpment of eastern Australia: tectonic and geomorphic significance.- Journal of the Geological Society of Australia, 29,13-22. DOI: https://doi.org/10.1080/00167618208729190 
Osborne, R.A.L., 1984: Multiple karstification in the Lachlan Fold Belt in New South Wales: Reconnaissance Evidence.- Journal and Proceedings of the Royal Society of New South Wales, 107,15-34.

Osborne, R.A.L., 1986: Cave and landscape chronology at Timor Caves, New South Wales.- Journal and Proceedings of the Royal Society of New South Wales, 119, 1/2, 55-76.

Osborne, R.A.L., 1991: Palaeokarst deposits at Jenolan Caves, N.S.W.- Journal and Proceedings of the Royal Society of New South Wales, 123, 3/4, 59-73.

Osborne, R.A.L., 1993a: A new history of cave development at Bungonia, N.S.W.- Australian Geographer, 24,1, 62-74. DOI: https://doi. org/10.1080/00049189308703078

Osborne, R.A.L., 1993b: Geological Note: Cave formation by exhumation of Palaeozoic palaeokarst deposits at Jenolan Caves, New South Wales.- Australian Journal of Earth Sciences, 40, 591-593. DOI: https://doi.org/10.1080/08120099308728106

Osborne, R.A.L., 1993c: The history of karstification at Wombeyan Caves, New South Wales, Australia, as revealed by palaeokarst deposits.- Cave Science, 20, $1,1-8$.

Osborne, R.A.L, 2000: Paleokarst and its significance for speleogenesis.- In Klimchouk, A.B. et al. (eds.) Speleogenesis, Evolution of Karst Aquifers. National Speleological Society, pp. 113-123, Huntsville.

Osborne, R.A.L., 2002: Paleokarst: Cessation and rebirth? In Gabrovšek, F. (ed.) Evolution of karst: from prekarst to cessation. Založba ZRC, pp. 97-114, Ljubljana.

Osborne, R.A.L., 2003: Partitions, compartments and portals: Cave development in internally impounded karst masses.- Speleogenesis and Evolution of Karst Aquifers: The virtual Scientific Journal, 1,4, 1-12. DOI: https://doi.org/10.5038/1827-806x.34.1.6

Osborne, R.A.L., 2004: Paleokarst.- In Gunn, J. (ed.) Encyclopedia of Cave and Karst Sciencet. Fitzroy Dearborn, pp. 559-561, New York. DOI: https://doi. org/10.4324/9780203483855

Osborne, R.A.L., 2005: Dating ancient caves and related palaeokarst.- Acta Carsologica 34,1, 51-72.

Osborne, R.A.L, 2007a: The world's oldest caves: - how did they survive and what can they tell us?- Acta Carsologica, 36,1,133-142. DOI: https://doi. org/10.3986/ac.v36i1.215

Osborne, R.A.L., 2007b: Intensely lithified palaeokarst deposits in Okno Cave, Demänovská Valley, (Slovakia).- Geologica Carpathica, 58, 6, 565-578.
Osborne, R.A.L., 2007c: Cathedral Cave, Wellington Caves, New South Wales, Australia. A multiphase, non-fluvial cave.- Earth Surface Processes and Landforms, 32, 2075-2103. DOI: https://doi. org/10.1002/esp.1507

Osborne, R.A.L., 2007d: Geodiversity of Mole Creek Caves, Tasmania.- Report to the Australian Department of Environment and Water Resources, June 2007, pp. 64.

Osborne, R.A.L., 2010: Rethinking eastern Australian caves.- In: Bishop, P. (eds.) Australian Landscapes. Geological Society of London Special Publication 346, 289-308. DOI: https://doi.org/10.1144/ $\operatorname{sp} 346.15$

Osborne, R.A.L., 2013: Preservation and burial of ancient karst.- In: Shroder, J.F. (ed) Treatise on Geomorphology. Volume 6, Academic Press, pp. 95-103, San Diego. DOI: https://doi.org/10.1016/b978-012-374739-6.00132-9

Osborne, R.A.L \& I. B. Cooper, 2001: Sulfide-bearing palaeokarst deposits at Lune River Quarry, Ida Bay, Tasmania.- Australian Journal of Earth Sciences, 48, 401-416. DOI: https://doi.org/10.1046/j.14400952.2001.00868.x

Osborne, R.A.L., Weliange, W.S., Jayasingha, P., Dandeniya, A.S, Algiriya A.K.P.P. \& R. E. Pogson, 2013: Caves and karst-like features in Proterozoic gneiss and Cambrian granite, southern and central Sri Lanka: An Introduction.- Acta Carsologica, 42,1, 25-48. DOI: https://doi.org/10.3986/ac.v42i1.630

Osborne, R.A.L., Zwingmann, H., Pogson, R.E \& D.M. Colchester, 2006: Carboniferous clay deposits from Jenolan Caves, New South Wales, Australia.- Australian Journal of Earth Sciences, 53, 3, 377-405. DOI: https://doi.org/10.1080/08120090500507362

Plotnick, R.E., Kenig, F \& A.C. Scott, 2015: Using the voids to fill the gaps: caves, time, and stratigraphy.- In: Smith, D. G. et al. (eds.) Strata and Time: Probing the Gaps in Our Understanding.- Geological Society, 233-250, London. DOI: https://doi. org/10.1144/sp404.5

Quinif, Y., Meon, H., \& J. Yans, 2006: Nature and dating of karstic filling in the Hainaut Province (Belgium). Karstic, geodynamic and paleogeographic implications.- Geodinamica Acta, 19. 2, 73-85. DOI: https://doi.org/10.3166/ga.19.73-85

Sass-Gustkiewicz, M. 1974: Collapse breccias in the orebearing dolomite of the Olkusz mine (Crakow- Silesian ore district).- Roczink Polskiego Towarzystwa Geologicznego, 44, 217-226. 
Vergari, A \& Y. Quinif, 1997: Les paleokarsts du Hainaut (Belgique).- Geodinamica Acta, 10, 4, 175-1 87. DOI: https://doi.org/10.1080/09853111.1997.11105 301

Wenrich, K.J. \& H.B. Sutphin, 1994: Grand Canyon caves, breccia pipes and mineral deposits.- Geology Today, May-June 1994, 97-104. DOI: https://doi. org/10.1111/j.1365-2451.1994.tb00880.x
Wright, V.P \& P.L. Smart, 1994: Chapter 13 Paleokarst (Dissolution Diagenesis): Its occurrence and hydrocarbon exploring significance.- In: Wolf, K.H. \& G.V. Chilingarian (eds.) Developments in Sedimentology.- Elsevier, 51, 477-517, Amsterdam. DOI: https://doi.org/10.1016/s0070-4571(08)70447-3 